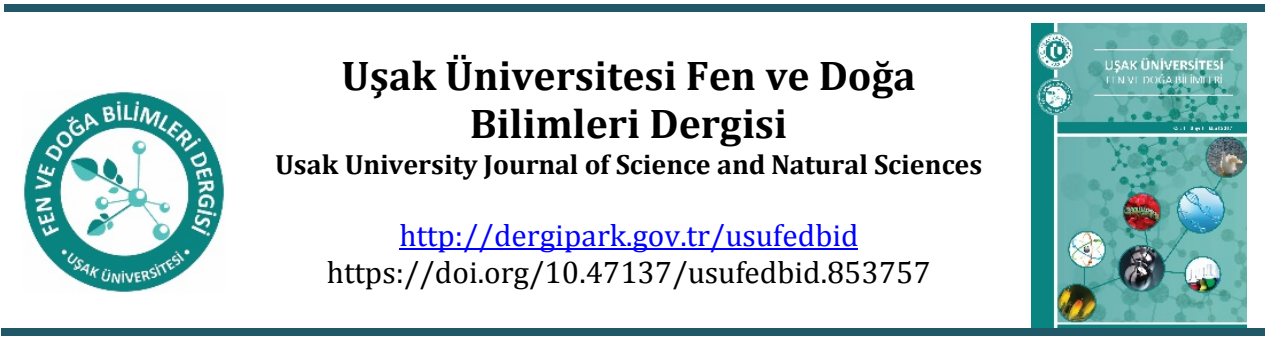

Araştırma makalesi

\title{
Farklı Boyutlardaki Poliamid, Poliester ve Jüt Liflerin Betonun Mekanik Davranışına Etkisi
}

\author{
Emine Arslan*, Hakan Sarıkaya \\ İnșaat Mühendisliği Bölümü, Mühendislik Fakültesi, Ușak Üniversitesi, Ușak, Türkiye \\ Geliş: 4 Ocak $2021 \quad$ Kabul: 27 Mart 2021/Received:4 January $2021 \quad$ Accepted: 27 March 2021
}

\begin{abstract}
Concrete is a brittle material with very low tensile strength and low tensile deformation capacity. In order to improve these properties of concrete, it is tried to improve the weak properties of concrete as a result of the addition of fibers with high technical properties made of different materials. In this study, the effect of fiber concrete samples produced from polyester, polyamide and jute fiber mixtures used in $0.5,1,1.5 \%$ ratios on the physical and mechanical properties was investigated by keeping the cement amount constant in the concrete mixtures. Standard cubic samples for concrete compressive strengths and beam samples for flexural-tensile strengths were produced. It was determined that as the fiber ratio increased, the Schmidt hardness and bending strength values increased, the collapse amount, thermal conductivity coefficient and compressive strength values decreased.. It is thought that the increase in fiber ratio will contribute to thermal insulation by decreasing the thermal conductivity value.
\end{abstract}

Keywords: Polyamide fiber, polyester fiber, jute fiber, fiber concrete.

\section{Özet}

Beton, çekme dayanımı ve çekme birim deformasyon kapasitesi çok düşük olan gevrek yapıdaki bir malzemedir. Betonun bu özelliklerinin geliștirilmesi amacıyla, beton içerisine değișik malzemelerden üretilmiş ve teknik özellikleri yüksek liflerin katılması sonucu, betonun zayıf özellikleri iyileştirilmeye çalışılmaktadır. Bu çalışmada, oluşturulan beton karışımlarında çimento miktarı sabit tutularak \% $0.5,1$, 1.5 oranlarında kullanılan poliester, poliamid 6,6 ve jüt lifi karışımlarından üretilen lifli beton numunelerinin, fiziksel ve mekanik özelliklerine olan etkisi incelenmiştir. Beton basınç dayanımları için standart küp numuneler ve eğilme-çekme dayanımları için kiriş numuneler üretilmiştir. Lif oranı arttıkça Schmidt sertliği ve eğilme dayanımı değerlerinin arttığı, çökme miktarı, ısıl iletkenlik katsayısı ve basınç dayanımı değerlerinin azaldığı tespit edilmiștir. Lif oranının artması ısı iletkenlik değerini azaltarak, ıSı yalıtımına katkı sağlayacağı düşünülmektedir.

Anahtar Kelimeler: Poliamid lifi, poliester lif, jüt lifi, lifli beton.

(C)2021 Usak University all rights reserved.

\footnotetext{
*Corresponding author: Emine Arslan

E-mail: arslan3632@gmail.com

ORCID ID: 0000-0003-4580-3029
}

(C)2021 Usak University all rights reserved. 


\section{Giriş}

Beton, insanlık tarihinin gelișiminde ve eski medeniyetlerin günümüze kadar gelebilen eserlerinde önemli bir yere sahiptir. Piramitlerin yapımında kireç bazlı bağlayıcıları kullanılmıș, Pantheon ve Colleseum gibi yapıların doğal hidrolik bağlayıcı olan puzzolanlar ile yapılmıș ve Orta Asya ile Anadolu'da Horasan Harcı adı verilen bir bağlayıcının kullanılmış olması beton olarak nitelendirilebilecek malzemelerin tarihinin çok eskilere dayandığını göstermektedir. Çağdaş beton kronolojisinin ise 1800'lü yılların başında Louis Vicat'ın ilk yapay çimentoyu üretmesi ve Joseph Aspdin 'in "Portland Çimentosu"nun patentini almasıyla başladığı düşünülmektedir. Betonarme yapı sistemlerinin bulunmasıyla, beton yaygın bir şekilde kullanılmaya başlamıștır. Günümüzde çok geniş bir kullanım alanı olan beton, sudan sonra dünyada en fazla tüketilen malzeme haline gelmiştir. Çok ekonomik, üretimi ve kullanımı kolay, uygun kullanımda güvenli, dayanıklı ve servis gerektirmeyen temel yapı malzemesidir.[1]

Geçmişten günümüze insanların en temel ihtiyaçlarından biri barınma olmuştur. İlkel çağlarda mağaralarla başlayan barınma ihtiyacı günümüzde yerini devasa gökdelenlere bırakmıştır. Bu yüzden yapı sektörü devamlı kendini yenileyen ve devamlı gündemde olan bir sektördür. Yapılardan istediğimiz özellikler gelişen teknolojiyle birlikte her geçen gün değișmekte ve önem kazanmaktadır. Yapı sektöründe en önemli elemanlardan biri de betondur. Ülkemiz deprem kuşağında yer aldığından afetlerde can ve mal kaybı yaşanmaması açısından betonun kalitesi ön plana çıkmaktadır. Ülkemizde betonun; yüksek katlı yapılardan barajlara, nükleer santrallerden beton yollara kadar geniş bir kullanım alanı vardır. Geleneksel beton bazı durumlarda teknik özellikleri bakımından yetersiz kalmaktadır. Geleneksel betonların eksik kaldığı durumlarda betondan istenilen özelliğe ve ihtiyaca bağlı olarak özel betonlar üretilmiştir. Özel betonlar geleneksel betondan malzeme ve karışım oranları, özellikleri ve uygulama açısından farklılık gösterir. Bu betonlardan bazıları; ağır betonlar, püskürtme betonlar, polimer betonlar, prepakt betonlar ve lifli betonlardır. Bu özel betonlardan bazıları uzun zamandır yapı sektöründe kullanılmasına rağmen, bazıları ise beton endüstrisine yeni kazandırılmaktadır. Yapı endüstrisinde ısı ve sese, yüksek ısıya dayanıklı, yüksek basınç dayanımlı, elde edilişi ve kullanımı kolay malzemelere ihtiyaç duyulmaktadır [2].

Beton; çimento, su, agrega ve gerektiğinde katkı maddelerinin (mineral, kimyasal, fiber vb.) belirli şartlarda ve oranlarda karıștırılmasıyla elde edilen, başlangıçta șekil verilebilen plastik formda olup, zamanla çimento ve su arasındaki hidratasyonun (hidratasyon) sertleşerek mukavemet kazanan, harç fazı ve agregadan hazırlanan kompozit bir yapı malzemesidir [3]. Betonun zayıf özelliklerinin belirgin olarak iyileștirilmesi ve güçlendirilmesi için beton içerisine değişik malzemeler katılarak teknik özellikleri geliştirilebilmektedir [4]

Özel amaçlar ve kullanımlar için geliştirilmiş olan birçok farklı tip özel betonlar bulunmaktadır. Genelde, portland çimentosu matris fazı ve/veya agrega fazı bir şekilde değișime uğratılarak bazı beton özelliklerin değiștirilmesi, iyileștirilmesi ve/veya betona yeni bazı özelliklerin kazandırılması amaçlanmaktadır. Bu özel tip betonların bazıları çok uzun zamanlardan beri inșaat sektöründe kullanılmalarına rağmen, bazıları ise beton endüstrisine yeni kazandırılmaktadır.[5]

Yapı malzemeleri alanında son yıllarda yapılan çalışmaların bir sonucu olarak önemli bir yenilik meydana gelmiștir. Lifli beton teknolojisi adı verilen bu çalıșmalar, beton ve çimentolu malzemelerde çeșitli özelliklerde liflerin kullanımı esas almaktadır. Yapı malzemelerinde liflerin kullanılması aslında son yıllarda bulunan yeni bir kavram 
değildir ve birçok tarihi yapıda çeşitli organik liflerin kullanıldığı bilinmektedir. Ancak son yıllarda gelişen teknoloji sonucunda yüksek performanslı lifler ortaya çıkmış ve bu liflerin çimentolu kompozitlerde kullanımı da giderek yaygınlaşmıştır [6]. Beton içerisinde yaygın olarak kullanılan lifler; çelik, polipropilen, karbon ve alkali dirençli cam liflerdir. Lifli betonlarda, bütün lif çeșitlerinde sağlanması gereken en önemli özellik liflerin beton içerisinde homojen olarak dağılması ve bu dağılımın beton karıștırıldıktan sonra da bozulmamasıdır. Üniform bir șekilde dağılan lifler, beton içerisinde olușan çatlakları önlemekte ve çatlakların beton içerisinde ilerlemesini yavaşlatarak betonu daha dayanıklı hale getirdiği bilinmektedir. Bu özelliğinden dolayı lifli betonun çekme ve eğilme dayanımı artıran faktörler darbe etkisine karşı da dayanımı artırır. Bu nedenle betonarme kazık, yol, su boruları, genel olarak büyük fabrika inşaatlarının döşeme betonlarında ve prefabrike yapı elemanları üretiminde lifli betonların tercih edilmeleri halinde daha iyi sonuçlar alınacağı bilinmektedir [7].

Bu çalışmada poliester poliamid ve jüt lifleri kullanılmıştır. (Şekil 1) Poliester ve poliamid sentetik liflerdir. Poliamid lifi dünyada üretilen ilk sentetik liftir. İngiltere'de Terylene, Trevira, ABD'de Dacron, Almanya'da Diolen ve Türkiye'de Perilen ticari adları ile üretilen poliester lifleri günümüzde en çok kullanılan sentetik lif konumundadır.

Petrokimya ve tekstil endüstrisinde yapılan araştırmalar ve gelişmeler sonucu sentetik polimer lifleri üretilmiştir. Akrilik, aramid, naylon, polyester ve polietilen ve polipropilen başlıca sentetik liflerdir. Hepsinin de çok yüksek çekme dayanımları vardır. Fakat bu liflerin çoğu aramid hariç düşük elastiklik modülüne sahiptirler. Sentetik liflerin kalitesi çap ve uzunluk oranlarına bağlıdır. Çapları mikron düzeyindedir. Bu lifler tekil ya da lif hamuru halinde bulunurlar. FRC (lif takviyeli beton) de kullanılanların uzunlukları 0,5-2 inç (12-50 mm) arasında değişir. Bazı lif tipleri çok kısa (1-2) mm olabilir, çok uzun olanları da vardır. Uygulanacak yerin ihtiyacına göre tipler artırılır. Petrokimya ve tekstil endüstrisinde yapılan araştırmalar ve gelişmeler sonucu sentetik lifler üretilmiştir.[8]

Doğal bir lif olan jüt ise Bangladeş, Çin, Hindistan ve Tayland'ta yetişir. Bu bitkilerin uzunlukları 2,4 m ve sap çapları $25 \mathrm{~mm}$ den az olur. Kabukları liflidir. Bu kabuk suya batırıldığında, içine su alır ve lifleri gevşer, bu lifler el ile ayrılır ve kurutulur. Son zamanlarda bu işlem için mekanik aletler de geliştirilmiştir. Jüt bitkileri çekme gerilmesinde dayanıklıdır. Geleneksel olarak bu lifler halat, çuval, çanta ve giysi yapımında kullanılır.[8]

Binici ve arkadaşları (2008) yapmış oldukları çalışmada beton bir kirişe çelik donatı yerine polyester lifler \%0,01 \%0,02 \% 0,03 oranında katılarak kirişin eğilme ve basınç özellikleri incelemişlerdir. Lif oranı arttıkça eğilme dayanımının arttığı gözlemlenmiştir. Lif katkısı basınç dayanımda lif oranı arttıkça azda olsa bir düşüşe neden olmuştur. Normal betona eklenen polyester lif, betonun eğilme dayanımına ve şekil değiștirme gibi elastik özelliklerine katkı sağlamıștır. Yüksek betonarme yapıların deprem kuvvetleri altında davranışını lifli betonlarla elde edilen süneklik düzeyinin olumlu yönde etkileyeceği düşünülmektedir. Atık bir lif olan polyesterle yapılan bu çalışma sonucunda atık lifin ekonomiye kazandırılabileceği ve kirişin eğilme dayanımına lifin katkıda bulunabileceğini gözlemlemişlerdir. [9] Güler ve Yavuz (2017) düşük hacimsel oranlarda lif katkılı betonun mekanik özelliklerini incelemişlerdir. Bu çalışmada çelik ve sentetik liflerin ayrı ayrı ve birlikte kullanılmasıyla oluşturulan karışımların basınç, eğilme ve yarmada çekme dayanımları karşılaştırılmıştır. Sentetik lif olarak poliamid lifi kullanılmıştır. Betonun içerisine \% 0,25 \% 0,5 \% 0,75 hacimsel oranlarında çelik ve sentetik lifler eklenmiştir. Lifler $12 \mathrm{~mm}$ ve $54 \mathrm{~mm}$ olmak üzere iki farklı uzunlukta kullanılmıştır. 12 mm sentetik lif içeren gruplarda basınç dayanımında artış olmamıştır. 
$54 \mathrm{~mm}$ sentetik lif içerenlerde ise basınç dayanımı \%2 ile \%5 arasında artış göstermiștir. Sonuç olarak çelik, sentetik ve karma lif katılan betonda çekme ve eğilme dayanımları artmış; basınç dayanımı ise önemli bir artış göstermemiștir. Yarmada çekme ve eğilme dayanımları lif hacim oranı ve narinlik oranı arttıkça artmıștır. Basınç yarmada çekme ve eğilme dayanımlarının tümü incelendiğinde ayrı ayrı kullanılan çelik ve sentetik liflere göre çelik ve sentetik lifin bir arada kullanıldı̆̆ karma lifli kompozitlerde daha çok dayanım artıșı gözlemlenmiștir. [10] Susurluk ve diğerleri (2018) yapmıș oldukları çalıșmalarda polipropilen lifin betona katılmasıyla betonun mekanik özelliklerinin değișimini incelemiștir. Betonda çimento ağırlığı sabit tutularak çimento ağırlı̆̆ının \%1, $\% 2$ ve $\% 3$ oranında polipropilen lif kullanılmıștır. Calıșmaların sonucunda polipropilen lifli betonların akıcı kıvamlı betonlarda çökme miktarını azalttığı gözlenmiștir, ișlenebilirliği olumsuz yönde etkilediği düșünülse bile bu durum taze betonun kohezyonu açısından önemlidir. Polipropilen lifli numunelerde lif miktarı arttıkça ultrases hızlarında bir artış gözlenmiştir. Lif miktarı arttıkça basınç dayanımı azalmıștır. Eğilme dayanımı ise lif miktarı arttıkça artmıștır. Saha beton uygulamalarında polipropilen lifli betonların kullanılabileceği bu çalışma ile gözlemlenmiştir. [11] Açıkgenç ve diğerleri (2012) yapmış olduğu çalıșmada farklı karıșımlara sahip polipropilen lifli betonların mekanik özelliklerini incelemiștir. Betonun en büyük dezavantajı çekme dayanımının düșük olmasıdır. Betonun kullanım yerine ve kullanım amacına göre farklı özellikler beklenmektedir bunun içinde özel betonlar kullanılmaya bașlanmıstır, lifli betonda bunlardan biridir. Deneysel çalışmalarda $150 \times 150 \times 150 \mathrm{~mm}$ küp ve $100 \times 100 \times 500$ mm kiriș ve $100 \times 100 \times 100 \mathrm{~mm}$ boyutlarında küp numuneler üretilmiștir. İki farklı lif türü kullanılmıștır. A tipi yumuşak küme halinde B tipi sert plastik olmak üzere iki adettir. Bu çalışmada asıl amaç uygulamada çok kullanılan A tipi lifli betondaki karışımdaki lif oranının beton özellikleri üzerindeki etkisini ölçmektir. Betonda lifler \%1 ve $\% 2$ kullanılmıștır. Bu çalışma sonucunda polipropilen lifin belirli orana kadar çekme dayanımında artış gösterdiği görülmüștür. Polipropilen lifler işlenebilme özelliğinde düşüş göstermiştir. Bunun dışında olumsuz bir sonuç gözlenmemiştir. Betonun mekanik özelliklerini olumlu yönde etkilemiștir.[12] Literatürde betonda lif kullanılmasıyla ilgili çalışmaları incelediğimizde, lif kullanımının hacimce çok büyük olmadığını görüyoruz lif kullanımı genellikle önceki çalışmalarda genellikle hacimce \%2 oranını geçmemiştir

Bu çalıșmada kullanmıș olduğumuz poliester, poliamid 6,6 ve jüt lifleri çekme ve așınma dayanımları yüksek olduğu için tercih edilmiștir. Bu liflerden polyester lifi maliyet açısından uygun olduğu için seçilmiștir. Poliamid lifi ise dayanım olarak poliester lifinden daha yüksek dayanıma sahip yapay bir lif olmasından ötürü tercih edilmiștir. Jüt lifi yaygın olarak üretilen dayanımı çok fazla olan doğal bir lif olduğu için tercih edilmiștir. Bu üç lifin betonun mekanik özelliklerini geliştirmeye katkı sağlayacağı düşünülmektedir. 

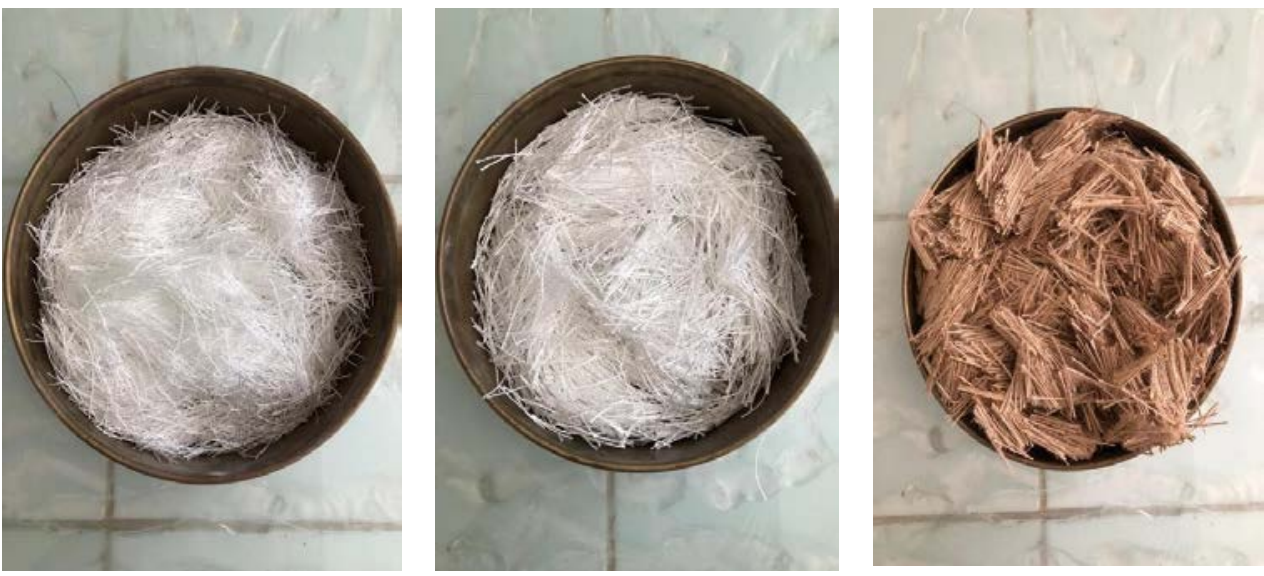

Şekil 1. Poliamid 6,6 lifi, Poliester lifi, Jüt lifi

\section{Materyal ve Yöntem}

Bu çalışmada, C 30 betonu için çimento miktarı sabit tutularak çimento ağırlığının \% 0,5, $\% 1$ ve \% 1,5 oranlarında poliester poliamid 6,6 ve jüt lifi kullanılarak $10 \times 10 \times 10 \mathrm{~cm}$ ebatlarında her seriden 10 adet küp, her seriden $10 \times 10 \times 40 \mathrm{~cm}$ ebatlarında her seriden 4 adet kiriş numuneleri üretilmiştir. Üretilen serilerde lifler ikili olarak kombine edilip lif boyları $3 \mathrm{~cm}, 4,5 \mathrm{~cm}$ ve $6 \mathrm{~cm}$ olan liflerden lif boyuna göre ve çimentonun ağırlıkça \% 0,5, $\% 1$ ve \%1,5 oranlarında lifler karıştırılarak karışım yapılmıştır. Bunlara ek olarak C 30 betonundan şahit numuneler üretilmiștir. Kullanılan çimentonun fiziksel ve mekanik özellikleri Tablo 1'de, çimento, normal agrega ve çimentonun kimyasal özellikleri Tablo 2'de, betonda kullanılan kimyasal katkının fiziksel ve mekanik özellikleri Tablo 3'te, poliamid ve poliester liflerinin fiziksel özellikleri ise Tablo 4 ve jüt lifinin fiziksel özellikleri ise Tablo 5' te verilmiștir.

Tablo 1. Çimentonun fiziksel ve mekanik özellikleri [13]

\begin{tabular}{ll}
\hline Bileşenler & CEM I 42,5 R (\%) \\
\hline Özgül ağırlık (gr/cm³) & 3,11 \\
Priz Başlangıcı (dk.) & 169 \\
Priz Sonu (dk.) & 255 \\
Hacim Genleşmesi (mm) & 0,77 \\
$\mathbf{2}$ Günlük Basınç Dayanımı (MPa) & 34 \\
28 Günlük Basınç Dayanımı (MPa) & 55,4 \\
\hline
\end{tabular}


Tablo 2. Normal agrega ve çimentonun kimyasal özellikleri [13]

\begin{tabular}{lll}
\hline Bileșen & CEM I 42,5 R (\%) & $\begin{array}{l}\text { Normal } \\
\text { Agrega(\%) }\end{array}$ \\
\hline SiO2 & 19,1 & 20,9 \\
Fe203 & 2,65 & 0,2 \\
Al203 & 5,19 & 0,4 \\
CaO & 63,40 & 42,8 \\
Mg0 & 1,83 & 0,4 \\
SO3 & 2,95 & - \\
Ti02 & - & $<0,1$ \\
Na20 & 0,22 & $<0,1$ \\
K20 & 0,94 & 0,1 \\
Cl- & 0,011 & - \\
P205 & - & $<0,1$ \\
MnO & - & $<0,1$ \\
Kizdırma Kaybı & 3,77 & - \\
HCl' de Çözünmeyen & 0,32 & - \\
Kalıntı & - & - \\
Serbest Kireç & 0,84 & - \\
Alkali & - & - \\
Eșdeğer & & \\
Toplam & & \\
Katkı & &
\end{tabular}

Tablo 3. Kimyasal katkının fiziksel ve mekanik özellikleri [14]

\begin{tabular}{ll}
\hline & Teknik Veriler \\
\hline Görünüm & Kahverengi Sıvı \\
Yoğunluk & $1,05 \pm 0,02 \mathrm{~g} / \mathrm{cm}^{3}$ \\
pH & $3-7$ \\
Klor içeriği & $<0,1 \%$ (EN $480-10^{\prime}$ a göre) \\
Alkali içeriği & $<10$ (EN 480-12'a göre) \\
Standartlara uygunluk & TS EN 934-2 \\
\hline
\end{tabular}


Tablo 4. Liflerin \%65 bağıl nem ve 20 C sıcaklıkta gerilim özellikleri [15]

\begin{tabular}{lllcl}
\hline Lifler & $\begin{array}{l}\text { Mukavemet } \\
\text { (N/tex) }\end{array}$ & $\begin{array}{l}\text { Kopma } \\
\text { uzaması (\%) }\end{array}$ & $\begin{array}{c}\text { Kopma işi } \\
\text { (mN/tex) }\end{array}$ & $\begin{array}{l}\text { Başlangıç } \\
\text { Modülü (N/tex) }\end{array}$ \\
\hline $\begin{array}{l}\text { Orta } \\
\text { Mukavemet } \\
\text { Yüksek }\end{array}$ & 0,48 & 20 & 63 & 3,0 \\
$\begin{array}{l}\text { Mukavemet } \\
\text { Stapel Lif }\end{array}$ & 0,66 & 16 & 58 & 4,4 \\
\hline & 0,37 & 43 & 101 & 1,0 \\
$\begin{array}{l}\text { Orta } \\
\text { Mukavemet }\end{array}$ & 0,47 & Polyester (PES) & & \\
Yüksek & 15 & 53 & 10,6 \\
$\begin{array}{l}\text { Mukavemet } \\
\text { Stapel Lif }\end{array}$ & 0,56 & 7 & 22 & 13,2 \\
\hline
\end{tabular}

Tablo 5. Jüt lifinin fiziksel özellikleri [16]

\begin{tabular}{ll}
\hline Fiziksel Özellikler & Jüt Lifi \\
\hline Yoğunluk(g/cm3) & 1,48 \\
Gerilme Direnci (kN/mm2) & $410-780$ \\
Sertlik (kN/mm) & $10-30$ \\
Kopma Uzaması (\%) & 1,9 \\
Nem Emilimi (\%) & 12 \\
Ham Elyaf Fiyatları(Rs./kg) & $40-50$ \\
\hline
\end{tabular}

Beton numunelerin üretimi ve fiziksel mekanik özelliklerinin tespiti için yapllan deneyler Uşak Üniversitesi Mühendislik Fakültesi İnşaat Mühendisliği Bölümü Yapı Laboratuvarında gerçekleştirilmiştir. Isıl iletkenlik katsayısı deneyi için Ege Üniversitesi Makine Mühendisliği Mekanik laboratuvarında test yapılmıştır. Bu çalışmada toplamda lifli numune ve ayrıca kıyas yapılabilmesi amacıyla normal beton numunesi üretilmiștir. Üretilen numunelerin karıșım oranları Tablo 6' da verilmiştir. Numuneler üretilirken küp ve eğilme numunesi olmak üzere iki farklı şekilde üretilmiştir. Küp numuneler $100 \times 100$ $\times 100 \mathrm{~mm}$ boyutundaki küplere öncelikle küpler yağlanmış daha sonra sarsma tablası üzerine konmuş ve beton karışım harcı 3 aşamada her aşamada 10 saniye sarsma tablası ile sarsılarak doldurulmuştur. Sarma işlemi betonun içinde boşluk kalmaması homojen şekilde dağılması ve yerleşmesi için yapılmıștır. Küp numunelerde her seri için 10 adet üretilmiştir. Kiriş numuneler $100 \times 100 \times 400$ mm boyutunda sıkıştırmalı demir kalıplara aynı yöntemle yerleştirilmiştir. Kiriş numunelerinde her seriden 4 adet üretilmiştir. Üretilen numunelerin kodlamasında poliester lifi PES, poliamid 6,6 PA ve jüt lifi J olarak kodlanmıştır. Tüm numuneler 24 saat korunaklı bir alanda bekletilmiş lastik takozlar yardımı ile düzgün bir şekilde kalıplardan çıkarılmıştır. Numuneler deneyin yapılacağı güne kadar $20 \pm 2{ }^{\circ} \mathrm{C}$ derece kür havuzunda bekletilmiștir (Şekil 2). 

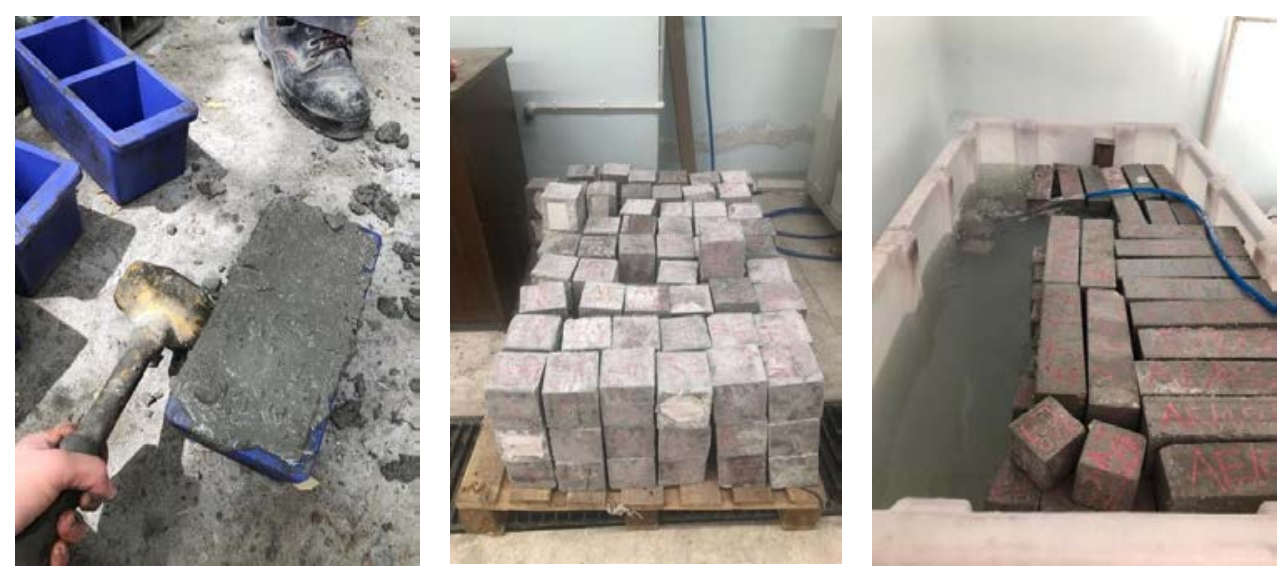

Şekil 2. Numunelerin yerleştirilmesi, kalıptan çıkartılması, kür havuzuna yerleştirilmesi 
Tablo 6. Üretilen Numuneler

\begin{tabular}{|c|c|c|c|}
\hline Kodu & Lif Boyu & Çimento & Lif \\
\hline & $(\mathrm{cm})$ & Ağırlığı(\%) & Oranları $(\%)$ \\
\hline NB & - & 100 & - \\
\hline PA-PES-0,5-3 & 3 & 99,5 & 0,5 \\
\hline PA-PES-1-3 & 3 & 99 & 1 \\
\hline PA-PES-1,5-3 & 3 & 98,5 & 1,5 \\
\hline PA-PES-0,5-4,5 & 4,5 & 99,5 & 0,5 \\
\hline PA-PES-1-4,5 & 4,5 & 99 & 1 \\
\hline PA-PES-1,5-4,5 & 4,5 & 98,5 & 1,5 \\
\hline PA-PES-0,5-6 & 6 & 99,5 & 0,5 \\
\hline PA-PES-1-6 & 6 & 99 & 1 \\
\hline PA-PES-1,5-6 & 6 & 98,5 & 1,5 \\
\hline PA-J-0,5-3 & 3 & 99,5 & 0,5 \\
\hline PA-J-1-3 & 3 & 99 & 1 \\
\hline PA-J-1,5-3 & 3 & 98,5 & 1,5 \\
\hline PA-J-0,5-4,5 & 4,5 & 99,5 & 0,5 \\
\hline PA-J-1-4,5 & 4,5 & 99 & 1 \\
\hline PA-J-1,5-4,5 & 4,5 & 98,5 & 1,5 \\
\hline PA-J-0,5-6 & 6 & 99,5 & 0,5 \\
\hline PA-J-1-6 & 6 & 99 & 1 \\
\hline PA-J-1,5-6 & 6 & 98,5 & 1,5 \\
\hline PES-J-0,5-3 & 3 & 99,5 & 0,5 \\
\hline PES-J-1-3 & 3 & 99 & 1 \\
\hline PES-J-1,5-3 & 3 & 98,5 & 1,5 \\
\hline PES-J-0,5-4,5 & 4,5 & 99,5 & 0,5 \\
\hline PES-J-1-4,5 & 4,5 & 99 & 1 \\
\hline PES-J-1,5-4,5 & 4,5 & 98,5 & 1,5 \\
\hline PES-J-0,5-6 & 6 & 99,5 & 0,5 \\
\hline PES-J-1-6 & 6 & 99 & 1 \\
\hline PES-J-1,5-6 & 6 & 98,5 & 1,5 \\
\hline
\end{tabular}

\section{Deneyler ve Sonuçlar}

Bu çalışmada su emme deneyi, tek eksenli basınç deneyi, üç eksenli eğilme deneyi, schimt sertlik çekici deneyi, ultrases deneyi ve ısıl iletkenlik katsayısı deneyi yapılmıştır.

\section{1. Çökme (Slamp) deneyi}

ASTM C143 (2000), TS EN 12350-2 (2002) ve birçok ülkede standart olarak da kabul edilmiştir. Abrams konisi olarak da isimlendirilen bu deneyde, Şekil 3'te görülen üst çapı $100 \mathrm{~mm}$, alt çapı $200 \mathrm{~mm}$ ve yüksekliği $300 \mathrm{~mm}$ olan tepesi kesik koni şeklindeki metal kalıp içine üç eşit tabaka halinde ve her tabakası $25 \mathrm{kez}$ özel bir çubukla (çapı $16 \mathrm{~mm}$, 
uzunluğu $600 \mathrm{~mm}$ ) şişlenerek taze beton doldurulmuştur. Daha sonra doldurulan beton sarsılmadan kesik koni kalıp yukarı çekilmiștir. Beton kendi ağırlığı ile bir miktar çökmüș ve çökme miktarı ölçülmüștür. Ölçülen değerler ise Şekil 4' te verilmiștir.

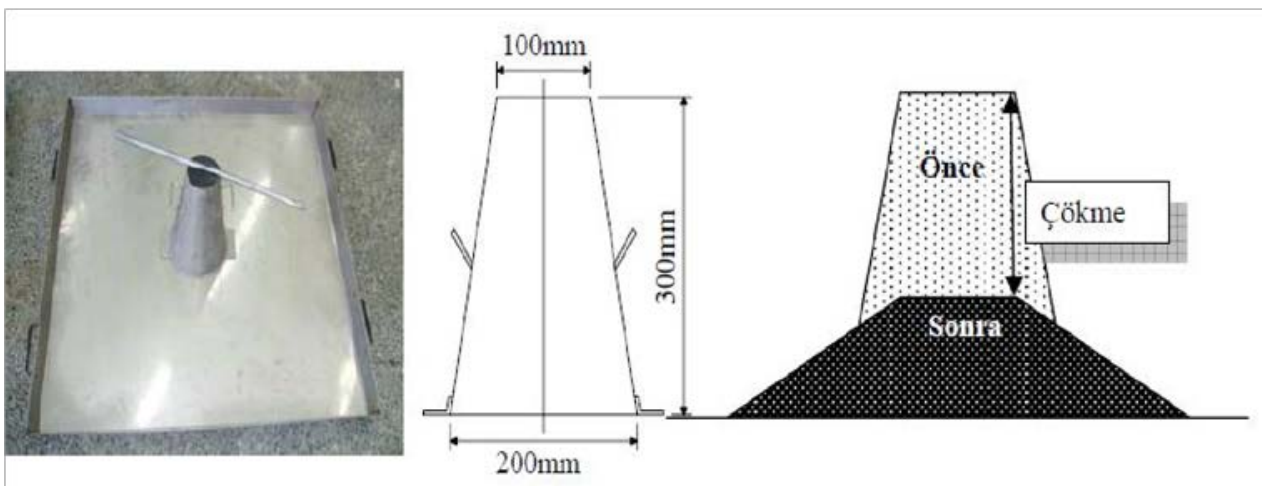

Şekil 3. Çökme deneyinde kullanılan aletler ve deneyin yapılışı [11]

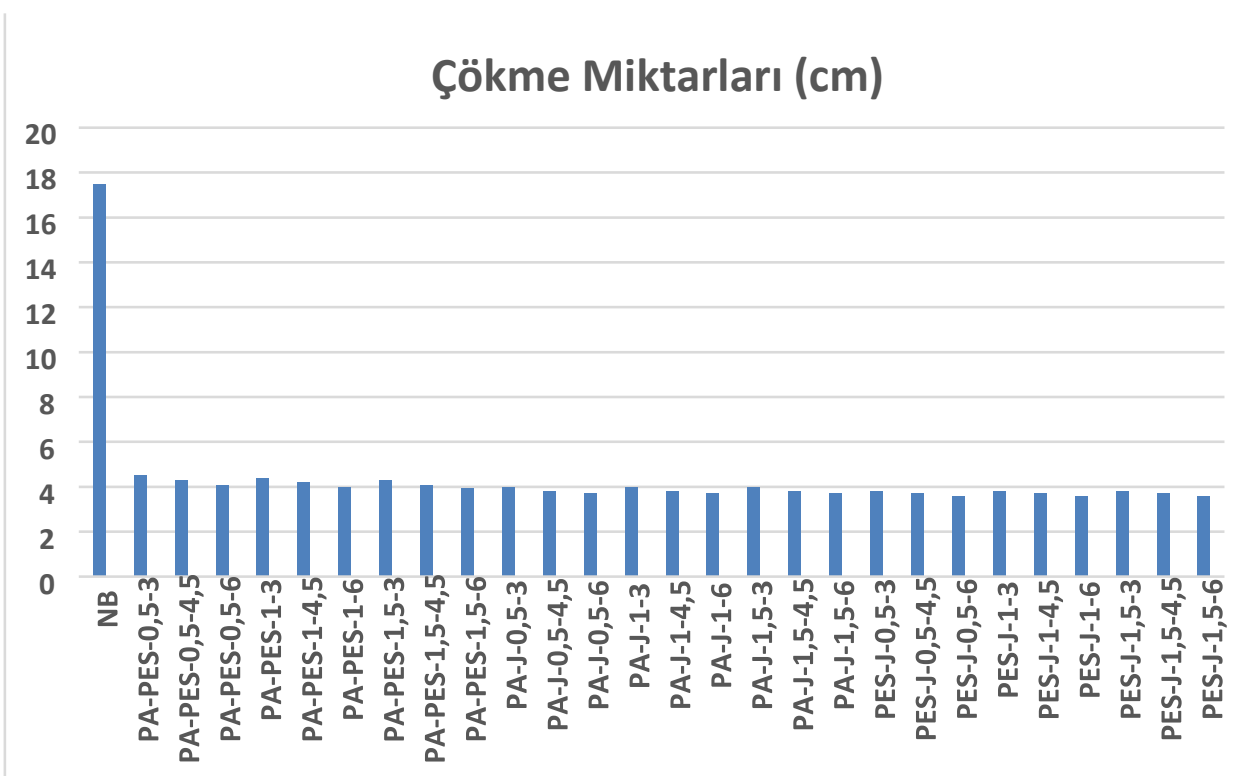

Şekil 4. Lifli betonların çökme değerleri

\subsection{Ultrases ölçüm deneyi}

Ultrases geçiş hızlarını ölçmek için Uşak Üniversitesi Mühendislik Fakültesi İnşaat Mühendisliği Bölümü Yapı Laboratuarında bulunan Ultrases ölçüm (Şekil 5) cihazı kullanılmıştır. Ultrases deneyi TSE EN 12504-4 (2012) standartına uygun olarak yapılmıştır. Ultrases hız ölçümü 12 voltluk akümülatör ile çalışan dijital göstergeli Ultrases ölçme aleti ile yapılmıştır. Aletin önce sıfır ayarı yapılmış sonra kalibre edilmiştir. Numunelerin her iki yanına gres yağı sürülerek proplar ile numune arasında boşluk oluşması önlenmiştir. Bu deneyde $10 \times 10 \times 10 \mathrm{~cm}$ boyutlarındaki lifli küp 
numunelerden her seriden 2 adet olmak üzere toplamda 54 adet ve 2 adet şahit numune kullanılmıştır. Küp numuneler üzerinde yapılan deney ile ses dalgaları geçirme süreleri ölçülmüştür. Ultrases hızı deney sonuçlarının değerlendirilmesinde mikro saniye (

olarak okunan Ultrases hızı geçiş süresi değerleri Eşitlik 1 ile hesaplanarak Ultrases hızı $\mathrm{km} / \mathrm{s}$ cinsinden hesaplanmıștır. Lifli betonların Ultrases hızları ölçüm sonuçları ise Şekil 6'da verilmiștir.

$\mathrm{V}=\mathrm{L} / \mathrm{t}$

(1)

V: Ultrases hizı(km/s),

L: Numune boyu (km),

t: Ultrases geçiş süresi (sn),

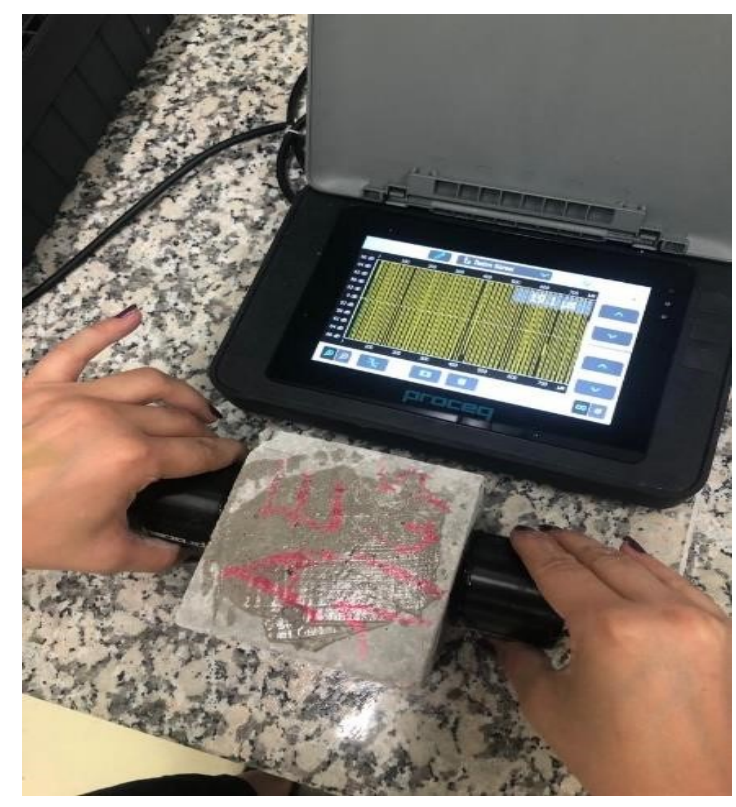

Şekil 5. Ultrases ölçüm deneyi 


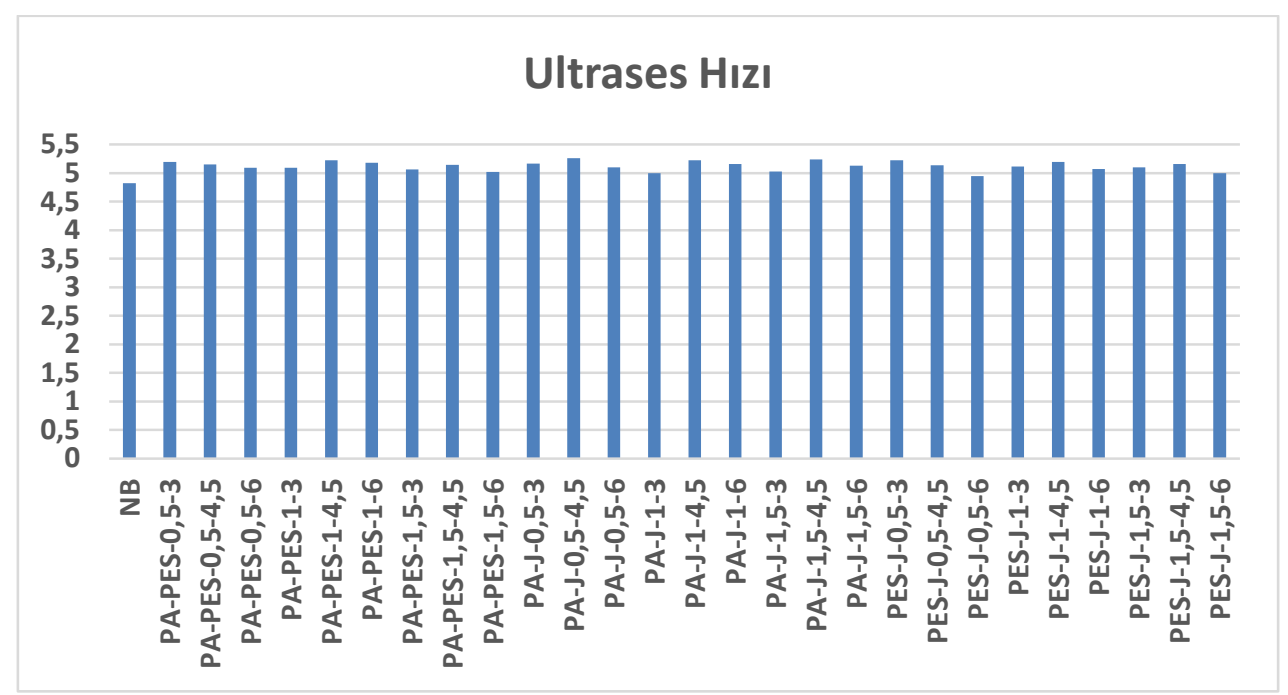

Şekil 6. Lifli betonların ultrases hızları deney sonuçları

\subsection{Su Emme Deneyi}

Kür havuzunda bekletilen $10 \times 10 \times 10 \mathrm{~cm}$ küp numunelerden her seriden ikișer tane olmak üzere toplamda 54 tane numune ve iki adet küp şahit numune sudan çıkarılıp önce yaş birim hacim ağırlıkları hassas terazi ile ölçülmüştür. 24 saat sonra kuruyan numunelerin kuru birim hacim ağırlıkları aynı hassas terazi ile tekrar ölçülmüş ve aşağıdaki değerler elde edilmiştir. Su içinden çıkarılan numunelerin suya doygun durumdaki ağırlığı ile kuruyan numunelerin ağırlığı arasındaki fark hesaplanarak ağırlıkça su emme değeri hesaplanmıştır. Su emme kapasitesi betona giren su miktarının betonun kuru ağırlığına bölünmesiyle bulunur ve yüzde olarak ifade edilebilir. Lifli betonların yaș ve kuru birim hacim ağırlık ölçüm sonuçları Șekil 7'de verilmiștir. Su emme deneyi TS 699 (2009)' a uygun olarak yapılmıștır. 


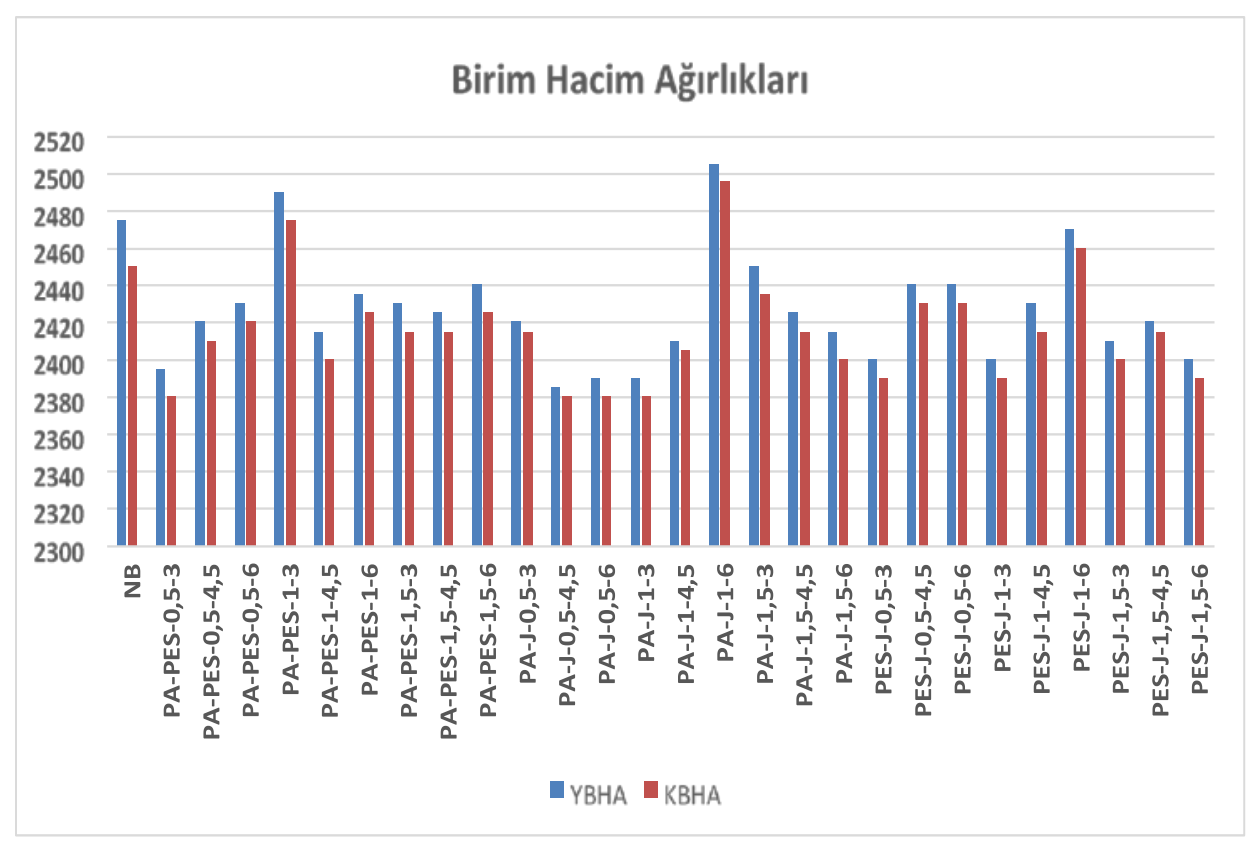

Şekil 7. Lifli betonların yaş ve kuru birim hacim ağırlıkları

\subsection{Tek Eksenli Basınç Deneyi}

Tahribatlı test yönteminde küp numuneler için tek eksenli basınç deneyi ve kiriş numuneler için üç eksenli eğilme deneyi yapılmıştır. Tek eksenli basınç deneyi TSE EN 12390-3 (2019) ve deneylerde kullanılan deney aleti TS EN 12390-4 (2019) 'e uygun olarak yapılmıştır. Tek eksenli basınç deney için Uşak Üniversitesi Yapı Malzemeleri Laboratuvarında bulunan 300 ton kapasiteye sahip tek eksenli basınç presi (Şekil 8) kullanılmıştır. Basınç deneylerinde yükleme hızı saniyede 0,35 MPa olarak sabit tutulmuştur. Bu deneyde $10 \times 10 \times 10 \mathrm{~cm}$ lifli küp numunelerden toplamda 162 adet ve 6 adet şahit numune deneye tabi tutulmuştur. Bu amaçla daha önceden hazırlanan küp beton numuneleri 7. ve 28. Günlerinde kırılarak kırılma anındaki okunan yük değeri Eşitlik 2'de yerine konularak beton numunesinin basınç dayanımı değerleri hesaplanmıştır. Lifli betonların 7. ve 28. günlük basınç dayanımları ölçüm sonuçları Şekil 9'da verilmiştir.

$$
\sigma={ }_{A}
$$

$\sigma$ : Basınç dayanımı (MPa)

$\mathrm{P}$ : Kırılma yükü $(\mathrm{N})$

A: Numunenin yük doğrultusundaki kesit alanı $\left(\mathrm{mm}^{2}\right)$ 


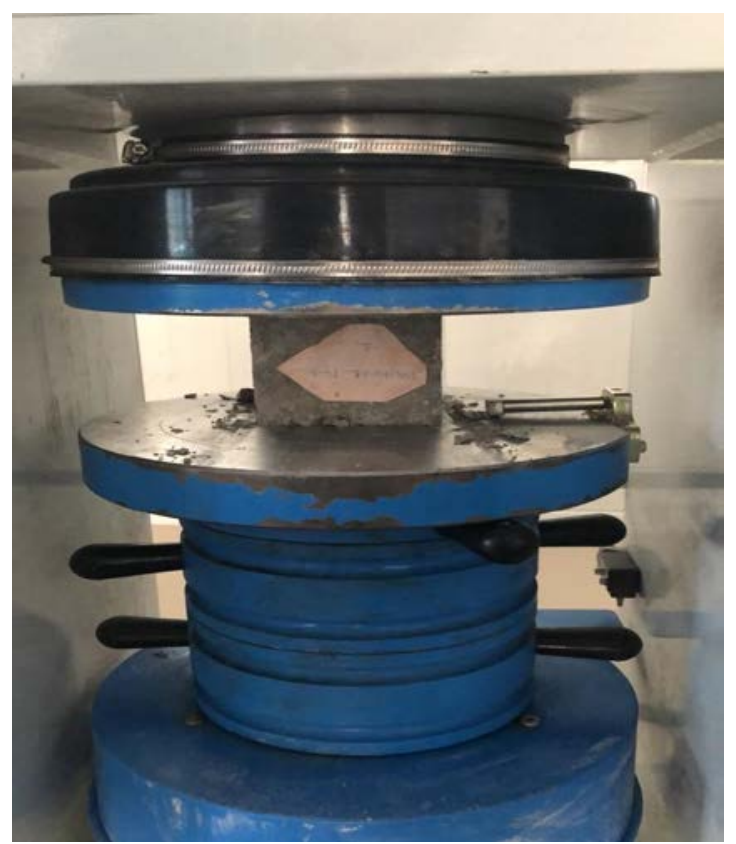

Şekil 8. Beton tek eksenli basınç deneyi

\section{7 ve 28 Günlük Basınç Deneyleri}

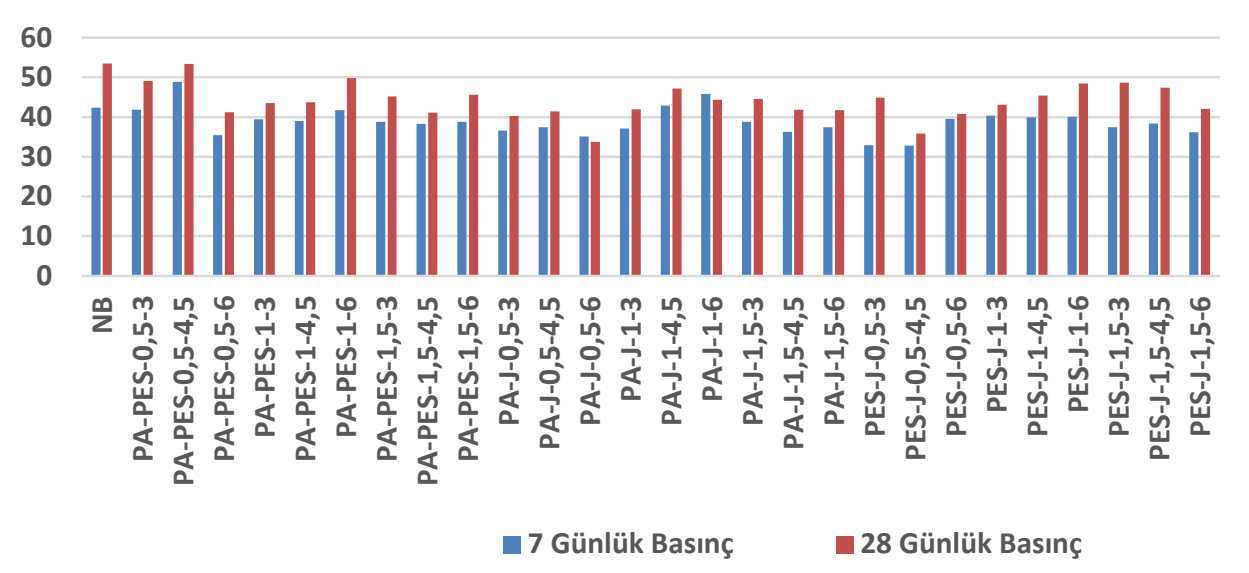

Şekil 9. Lifli betonların 7. ve 28. günlük basınç dayanımları ölçüm sonuçları

\section{5. Üç eksenli eğilme deneyi}

Kiriş numuneler için 3 nokta eğme deneyi uygulanmıştır (Şekil 10). $10 \times 10 \times 40 \mathrm{~cm}$ boyutundaki numunelerden 108 adeti tek noktadan basınca maruz bırakılmıştır ve eșitlik 3 yardımıyla eğilme dayanımları hesaplanmıştır. Eğilme deneyi TSE EN 12390-5 (2019)'e uygun olarak yapılmıştır. Lifli betonların 7. ve 28. günlük eğilme dayanımları ölçüm sonuçları Şekil 11'de verilmiştir. 
$\sigma=\frac{M}{W}=\frac{\frac{P \times L}{4}}{\frac{b \times h^{2}}{6}}$

?: Eğilme dayanımı ( kgf / 园²),

M: Maksimum moment,

W: Mukavemet momenti,

P: Kırılma yükü ( kgf),

b: Örnek genişliği,

h: Örnek yüksekliği,

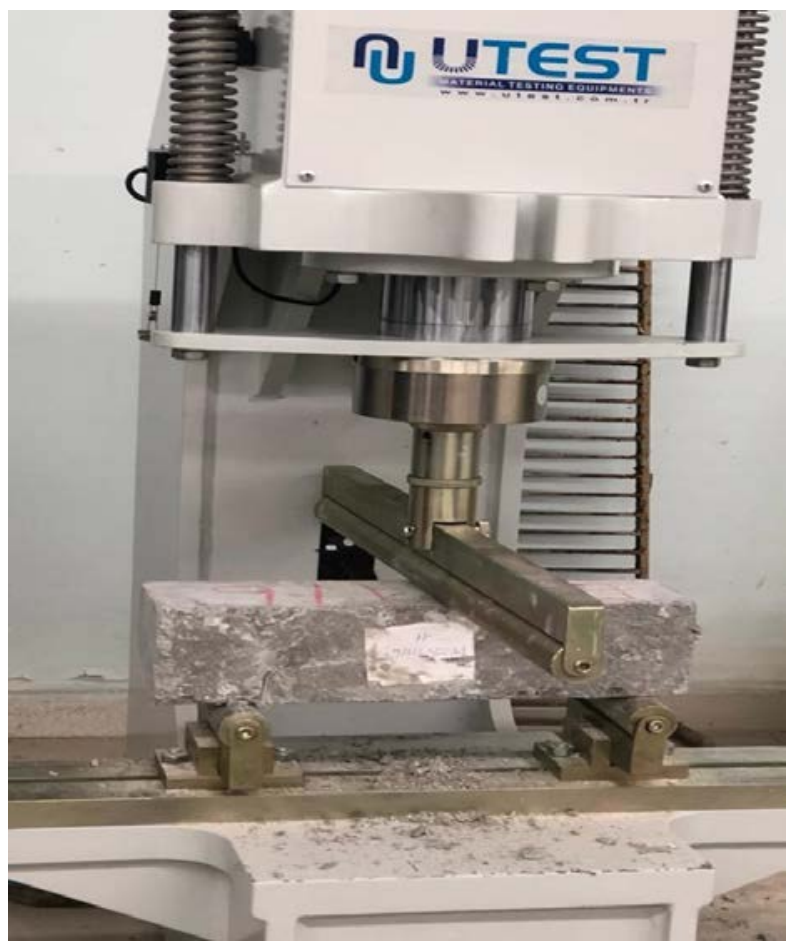

Şekil 10. Üç Eksenli Eğilme Deneyi 


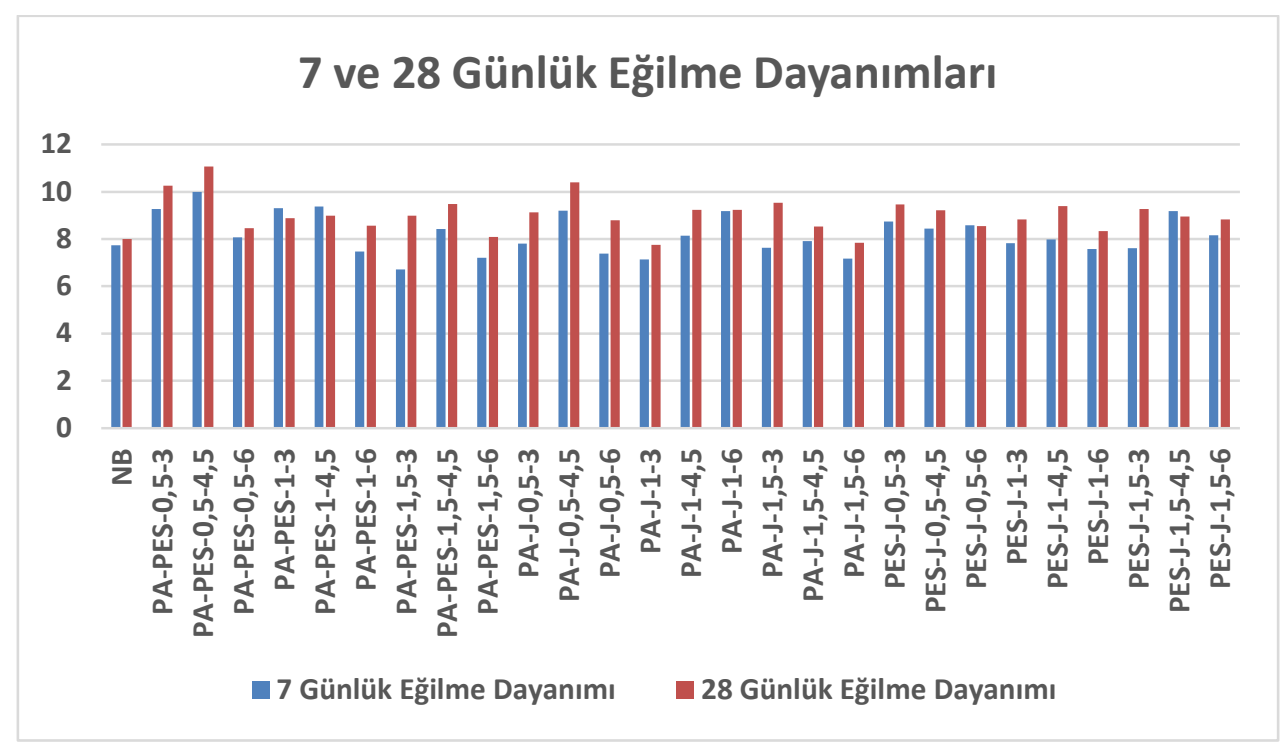

Şekil 11. Lifli betonların 7. ve 28. günlük eğilme dayanımları ölçüm sonuçları

\subsection{Schimt sertlik çekici deneyi}

Schmidt Sertlikler deneylerinde, deneye başlamadan önce Schmidt çekici kalibrasyon örsüyle kalibre edilmiştir. Deneylerde N tipi Schmidt çekici kullanılmıştır. Schmidt sertlik çekici deneyleri TS EN 12504-2 (2013) 'e uygun olarak gerçekleştirilmiştir. Beton dayanım deneyleri $10 \times 10 \times 10 \mathrm{~cm}$ boyutlarındaki 28 günlük küre tabi tutulmuş lifli küp beton numunelerinden 54 adeti üzerinde yapılmıştır. Deney her bir beton serisinden 2 adet olmak üzere her numunede 3 farklı noktadan ölçüm alınırak yapılmıştır. Küp numunelerin üst yüzeyinden $90^{\circ}$ açı ile (Şekil 12 den alınan 6 değerin aritmetik ortalaması alınarak o numunenin Schmidt çekici değeri belirlenmiştir). Bu değer dikkate alınarak çekiç üzerindeki abaktan o numunenin tek eksenli basınç dayanım değeri alınmıştır. Lifli betonların Schmidt Sertlik ölçüm sonuçları Şekil 13'te verilmiştir. 


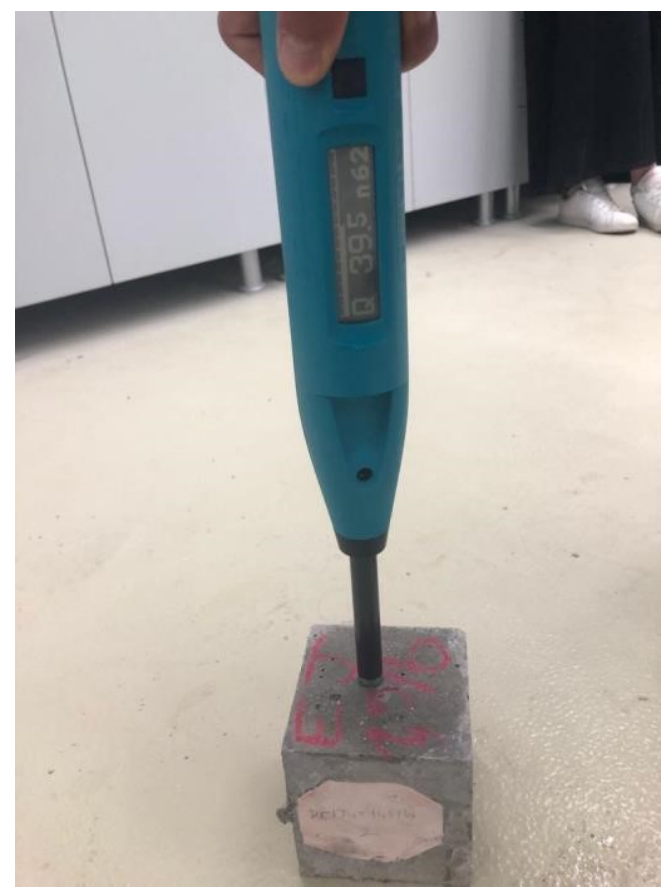

Şekil 12: Schmidt Sertlik deney aleti

\section{Schmit Deneyi Sonuçları}

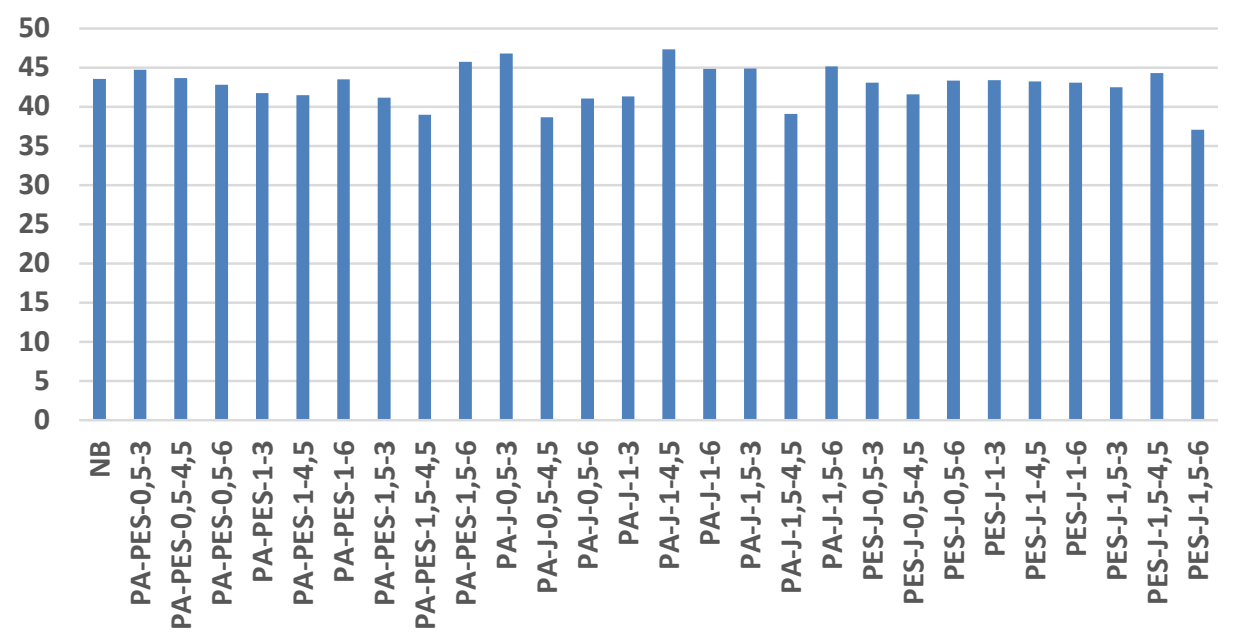

Şekil 13. Schmidt Sertlik deneyi sonuçları

\subsection{Isıl iletkenlik katsayısı deneyi}


Üretilmiş olan betonların ısı iletkenlik katsayısını saptamak üzere Ege Üniversitesi Mühendislik Fakültesi Makine Mühendisliği Laboratuvarı'nda yapılan deneyler için öncelikle 10 × 10 x $10 \mathrm{~cm}$ olan küp numuneler kesilerek 10 × 5 x $2 \mathrm{~cm}$ hale getirilmiștir. Her seriden birer adet lifli numune kesilerek 27 adet lifli numune ve şahit numuneler üzerinde deney yapılmıștır. Isıl iletkenlik deneyi için kesilen numune ve isıl iletkenlik deney aleti Șekil 14'te verilmiștir. Bu deneyde QTM-500 cihazı kullanılmış olup deney cihazı ASTM 1113-90 standartına sahiptir. Homojen bir malzemenin ısı iletkenliği, dengeye ulaşmış şartlar altında, iki yüzey sıcaklığı arasındaki fark $1{ }^{\circ} \mathrm{C}$ olduğu zaman, birim zamanda, birim alan ve dik yöndeki birim kalınlıktan geçen ısı miktarıdır. Yapı ve çeșitli ısı yalıtım malzemesinin ısı iletkenliğinin ölçümü, kararlı durumda ve geçiș durumunda olmak üzere iki yöntemle yapılmaktadır. Alıșılmıș yöntem, kararlı durumda ısıtılmıș plaka yöntemidir. Bu metodla ısıtılmıș bir plakanın iki tarafına simetrik olarak yerleștirilen, levha biçiminde muayene örneğinin, ortalama ısı iletkenliği bulunur. Geçiş durumunda ölçüm yapan cihazlar, daha ufak boyutlardaki malzemenin isı iletkenliğini daha kısa sürede saptayabilmektedir [17]. Lifli betonların ısıl iletkenlik katsayısı ölçüm sonuçları Şekil 15'te verilmiştir.

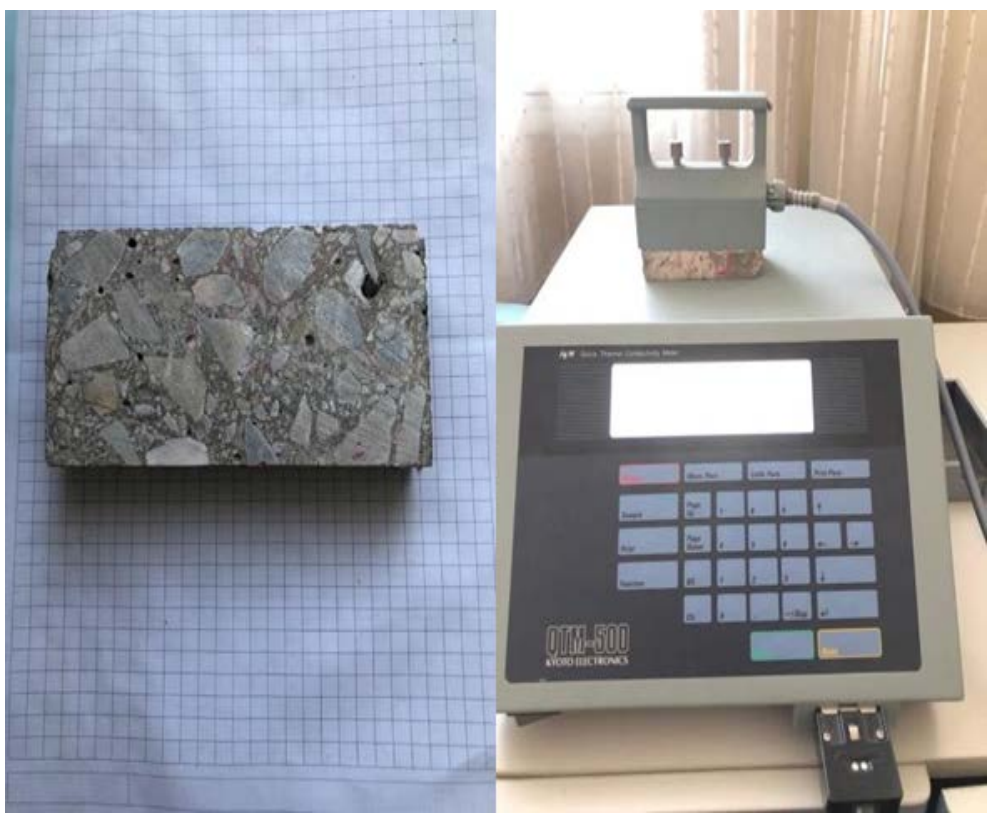

Şekil 14. Isıl iletkenlik deneyi için kesilen numune ve ısıl iletkenlik deney aleti 


\section{Isı İletkenlik Katsayısı}

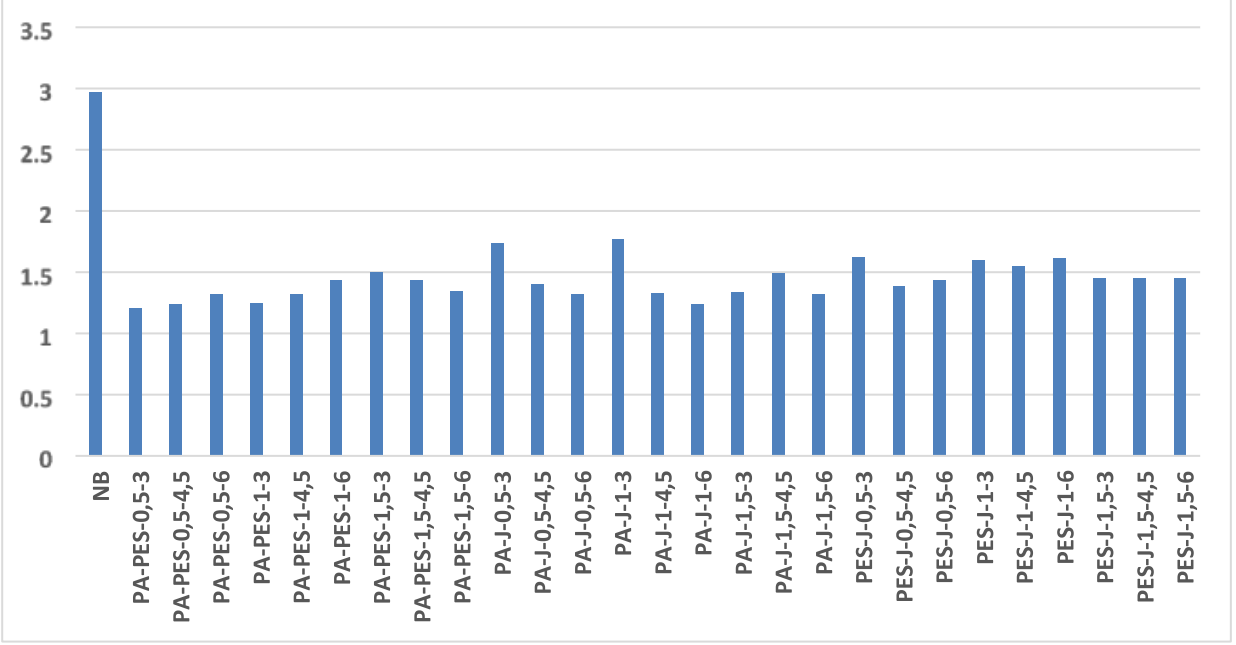

Şekil 15. Isıl iletkenlik katsayısı ölçüm sonuçları

\section{Sonuçlar}

Genel sonuç olarak lifli betonların kullanılması teknik olarak betonda sıkıntılı bir durum yol açmadığı gibi betona sayısız fayda sağlamaktadır. Akıcı kıvamlı betonlarda artan lif katkısı çökme miktarını azaltmıştır. Bu durum işlenebilirliğe olumsuz bir etki gibi görülse bile taze betonun kohezyonu açısından önemli bir özelliktir. 28 günlük basınç dayanım sonuçlarında artan lif katkısı basınç dayanımında kayba sebep olmuş fakat bu kayıp standartların içerisinde kalmaktadır. Basınç dayanımında en iyi katkıyı jut lifinin verdiği görülmektedir. 28 günlük eğilme dayanımı sonuçlarında artan lif katkısı eğilme dayanımında artışa sebep olmuştur. Tüm lifler olumlu sonuç vermiş olup lifler arasında belirgin bir fark olmadı̆̆ görülmektedir. Lif katkısı arttıkça su emme oranı, Schmidt sertlikleri ve ultrases hızlarında artış görülürken, ısıl iletkenlik katsayısında yaklaşık yarı yarıya tüm liflerde azalmıștır. Lif oranının artması tüm liflerde ısı iletkenlik değerini azaltarak ısı yalıtımına katkı sağlayacağı düşünülmektedir. Lif boylarının artması poliamid ve poliester karışımlarda ısı iletkenlik değerini artırdığı, jüt lifinde ise düşürdüğü görülmektedir. Eğilme değerlerinde ise lif boyları 3 ve 4,5 cm de arttığg $6 \mathrm{~cm}$ de düştüğü görülmektedir. $4,5 \mathrm{~cm}$ den sonrasının kullanılmaması gerektiği görülmektedir. Lifli betonların kullanılması özellikle plastik rötre çatlaklarını iyileştirme sağlayabileceği ve hava alanı betonları, yol betonları gibi, yüzey alanı fazla olan betonlarda kullanılabileceği söylenebilir.

\section{Teşekkürler}

Beton dökümlerinde bize ev sahipliği yapan Oktaş Beton Santraline ve çalıșanlarına teşekkürlerimizi sunarı. 


\section{Kaynaklar}

1. Karakule F, Akakın T. Hazır Beton Sektörünün Gelişimi ve Özel Beton Uygulamalarının Türkiye'deki Durumu. Yüksek Performanslı Betonlar: 6. Ulusal Beton Kongresi; 2005; İTÜ Süleyman Demirel Kültür Merkezi. İstanbul: Göksu Matbaa; 2005: 113-124.

2. Baradan B. Yapı malzemesi II DEÜ. İzmir(Türkiye): Mühendislik Fakültesi Basım Ünitesi; 2000.

3. Özel C. Katkılı betonların reolojik özelliklerinin taze beton deney yöntemlerine göre belirlenmesi, Doktora Tezi, Süleyman Demirel Üniversitesi Fen Bilimleri Enstitüsü, Isparta, Türkiye, 2007.

4. Topçu İB. Beton teknolojisi. Eskișehir: Uğur Ofset AŞ; 2006.

5. Özturan T. Özel betonlar. Hazır Betonlar, 2013(Temmuz-Ağustos) ;(118): 70-83.

6. Yardımcı MY. Çelik lifli kendiliğinden yerleșen betonların reolojik, mekanik, kırılma parametrelerinin araştırılması ve optimum tasarımı, Doktora Tezi, Dokuz Eylül Üniversitesi Fen Bilimleri Enstitüsü, İzmir, Türkiye, 2007

7. Ünal O. Isıl işlem uygulamasının lifli beton özelliklerine etkisi, Doktora Tezi, İstanbul Teknik Üniversitesi Fen Bilimleri Enstitüsü, İstanbul, Türkiye, 1994

8. Shah SP, Shao Y, Marikunte S. Extruded - Fiber reinforced composites. American Concrete Institute, 1995;17(4):48-53

9. Binici H, Gemci R, Türközer CD, Akdoğan O, Koç G. Polyester liflerle güçlendirilmiş beton kirişlerin mekanik özellikleri. Çukurova Üniversitesi Mühendislik Mimarlık Fakültesi Dergisi, 2008;23(2): 25-33

10. Güler S, Yavuz D. Düşük hacimsel oranlarda lif katkılı betonların mekanik özelliklerinin incelenmesi. Beton 2017 Hazır Beton Kongresi, 2017;13-14 Nisan 2017; İstanbul Fuar Merkezi; 34:98-107

11. Sarıkaya H, Susurluk G. Effect of polypropylene fiber addition on thermal and mechanical properties of concrete. Research on Engineering Structures \& Materials, 2019; 5(1):1-12.

12. Açıkgenç M, Arazsu U, Alyamaç KE. Farklı karışım oranlarına sahip polipropilen lifli betonların dayanım ve durabilite özellikleri. SDU Internatıonal Technologic Science, 2012;4 (3): 41-54

13. Çimsa Çimento. Cem I 42,5 R Çimentosunun kimyasal fiziksel ve mekanik özellikleri. Afyon Çimento Fabrikası. Afyon. 2019

14. Yapıchem. Yapı kimyasalları katoloğu. İstanbul. 2018

15. Morton WE, Hearte JWS. Physical properties of textile fibers. Fourt Edition. Cambridge(England): Woodhead Publishing Limited; 2008

16. Ramesh M, Palanikumar K, Reddy KH. Comparative evalution on properties of hybrid glass fiber - sisal/ jute reinforced epoxy composites. Procide Engineering, 2013;51:745-750 .

17. Sarıkaya H. Bor katkılı özellikli beton üretimi, Doktora Tezi, Süleyman Demirel Üniversitesi Fen Bilimleri Enstitüsü, Isparta, Türkiye, 2014. 